\title{
UNIVERSITY STUDENTS' OPINION WITH REGARD TO TAX FRAUD: A CASE STUDY OF UNIVERSITY OF ALICANTE, SPAIN
}

\author{
C. P. Sarasa ${ }^{1}$, J. Sarasa-Pérez ${ }^{2}$ \\ ${ }^{1}$ Universitat Politècnica de València (SPAIN) \\ ${ }^{2}$ University of Alicante (SPAIN)
}

\begin{abstract}
The taxes that are in place today are considered as powerful tools of solidarity and social cohesion. The taxation laws form part of a series of legal regulations which citizens must observe adequately in a democratic society. However, in the last years, a significant number of scandals related to tax evasion have arisen. This fact reveals huge discrepancies between theory and the real practices.

The purpose of this research is to try to determine how Spanish university students perceive tax fraud studying a sample of undergraduate students of the University of Alicante. The investigation aims to find some of the attitudes and opinions that can be determinant in the degree of justification or rejection of tax fraud. The conducted research also aims to identify what actions are perceived as the most efficient related to fight against tax evasion as well as the perceived effects of tax fraud.
\end{abstract}

Keywords: Tax fraud, Tax evasion, Undergraduate student, Spain, Education, University.

\section{INTRODUCTION}

The constitutional principles of justice and equality are the cornerstone of Spain's Treasury. This is why the taxation system described in the Spanish Constitution is based on the principles of economic capacity, justice, equality, progressivity and non-confiscation.

Tax fraud has a negative effect on the population as a whole and is particularly harmful to those who do fulfil their taxation responsibilities conscientiously. It denotes an inappropriate socialisation of the ethical values of solidarity and fairness.

This constitutes the framework for this study which analyses the attitude of university students towards tax fraud.

One of the mainstays of a proper socialisation of an individual is the educational system. If this system transmits the taxation obligation as an important part of social duty it will positively influence the attitude adopted towards the taxation system and the rejection of fraud.

\section{THEORETICAL FRAMEWORK}

There are other previous studies that have been conducted within the same framework as our project.

Park and Hyun [1] examine the determinants of greater tax compliance and conclude that education in taxation is one of the most effective tools for obtaining an improved compliance.

The study conducted by Eriksen and Fallan [2] analyses the influence of taxation knowledge on different attitudes towards tax fraud and on the perception of tax fairness. The study was carried out on a sample of university students before and after receiving a specific course on taxation, with positive results in the form of an improved perception of tax fairness and a stricter attitude towards tax fraud. The literature quoted by these authors referring to the study of the influence of education on attitudes towards fraud includes, among others, Vogel [3], Spicer and Lundsedt [4], Song and Yarbrough [5], Laurin [6], Kinsey and Gramisck [7]. These studies underline that, on the whole, education influences attitudes towards fraud, but without specifying whether taxation education or specific knowledge in taxation is important except for Song and Yarbrough [5]. They concluded that those with a higher level of taxation knowledge had greater tax awareness.

Prieto, et al., [8] analyse the variables that determine the attitude of Spaniards towards fraud from a double perspective. First, the social permissiveness towards taxpayers underreporting their income in order to reduce their tax burden is analysed. Second, they study the factors influencing the attitude of citizens towards those people who enjoy social and/or taxation benefits without having a right to them. 
In order to carry out this study, the authors use the database of the second study on religion, contained in the International Social Science Programme; ISSP. These authors analyse how the two types of fraud mentioned relate to a series of demographic, educational, social and political factors by estimating multivariate ordered probit models. They estimate the tax morale of the taxpayer by determining the permissiveness that the citizen has with regard to fraud.

Our study is related to these previous studies insofar as it researches the opinion and attitudes of a group of university students with respect to tax fraud, their perception of the fairness of the system and their opinion of taxes as factors that influence the degree to which tax fraud is justified. The results are compared with the results of a previous study developed with students of different undergraduate degree courses in Engineering and Management and Business studies at the Alcoy Campus of the Universitat Politècnica de València (UPV) [9].

\section{ANALYSIS OF THE ATTITUDE TOWARDS TAX FRAUD}

This study uses data obtained from a survey administered to the student population of the University of Alicante (UA). In general terms, this survey asks the students different questions regarding their opinion of the taxation system and its perceived fairness, and the effects of fraud and the measures to fight against it. The final sample comprised 157 valid surveys corresponding to students of Management and Business studies after receiving a specific course on taxation.

With respect to the first of the above-mentioned aspects, the questionnaire included the following questions:

Question 1. The students were asked to choose from three options the one which best reflected their opinion of taxes. Options: "1. Taxes are a means to better distribute wealth in a society; 2 . Taxes are necessary for the State to provide public services; 3 . Taxes are something which the State obliges us to pay without quite knowing in exchange for what."

The results of this question reveal that the majority of the respondents $(87.9 \%)$ know the ultimate purpose of taxation. Therefore, most of them are clear about the reason for taxes. In the previous study this percentage was $76.9 \%$ [9].

Question 2. "In general, taking into account the existing public services and provisions, would you say that as a whole society benefits a lot, quite a lot, not a lot, not at all from what we pay to the State in taxes?"

The data collected indicate that $54.8 \%$ of the respondents believe that society benefits a little from what the State is paid in taxes. $66.1 \%$ in [9].

Question 3. The participants in the survey were asked to say whether they considered the taxation system to be fair, choosing from three options: 1. Yes; 2. No; 3. Don't know/no answer.

$68.8 \%$ of them said that the Spanish taxation system is not fair. $15.9 \%$ considered that it is fair and another $15.3 \%$ did not know or did not answer.

The results of the study with students of different undergraduate degree courses [9] were: $85.8 \%$ of them said that the Spanish taxation system is not fair, $7.3 \%$ considered that it is fair and another $6.9 \%$ did not know or did not answer. This majority opinion largely coincided with the results obtained by the Spanish Sociological Research Centre (Centro de Investigaciones Sociológicas, CIS) [10] where $88.9 \%$ of those surveyed on a national scale considered taxes in Spain to be unfair. The percentage of those who considered that taxes were fair were similar in both cases $(7.3 \%$ and $6.8 \%$, respectively). However, regarding the fairness of the Spanish taxation system the opinion of the UPV students were slightly more positive than the rest of citizens. Our present study distances itself from results obtained by the Spanish Sociological Research Centre (we obtain better results).

With respect to this point it is worth pointing out that "this constant perception of an absence of equality in the taxation system is related to behaviour that is unfavourable towards the taxation system and more favourable towards tax fraud. This feeling of unfairness can be both a cause and an effect of fraud" [11]. Gutiérrez Lousa [12] indicates that if citizens perceive unfairness in the taxation system they can justify their fraudulent behaviour as a mechanism of sharing the tax burden more equally which legitimises their behaviour, preventing feelings of guilt. On the other hand, citizens who fulfil their tax obligation perceive that the taxation system is unfair as it permits other citizens to avoid paying their taxes. 
Question 4. In relation to the previous question it was asked "Why do you consider the Spanish taxation system to be unfair?" The answer options were: "1. Too much is paid to the state; 2 . The richest people do not pay what corresponds to them; 3 . Fraud control is insufficient; 4 . The public services and provisions are on the whole inefficient and of a poor quality; 5 . The taxpayer's money is not administered correctly; 6 . Another reason; 7. Don't know / no answer."

$40.7 \%$ believe that the taxation system is not fair because fraud control is insufficient $(32.1 \%$ in the study previously conducted [9]). In second place, with $22.2 \%(26.6 \%)$ are those who think that those with the most money do not pay what corresponds to them. $15.7 \%(16.1 \%)$ believe that the taxpayers' money is not administered correctly and $7.4 \%(10.1 \%)$ consider that public services and provisions are on the whole inefficient and of a poor quality. $4.6 \%$ consider that too much is paid to the state. In this question, the most-chosen answer directly relates the perception of the unfairness of the system with tax fraud, a subject which is the main object of the subsequent questions in the survey.

Question 5. This question asks the participants about the justification of fraud. $76.4 \%$ say that fraud is not justified in any case. This percentage contrasts with $56.4 \%$ obtained when student surveyed were not only management and business students but also engineering students with no specific tax training.

Question 6. This question evaluates the perception that the respondents have of the effectiveness of the Tax Authority in the fight against fraud. In this respect, it is worth highlighting that one third of the responses received (33.1\%) consider that the Tax Authority is not at all effective in fighting against fraud (50.9\% was achieved in the earlier study [9]). 54.8\% consider that the Tax Authority is only a bit effective in fighting against fraud.

Question 7. This question asks the respondents what they consider to be more effective in the fight against fraud, with the options being: "1. Punishment of the offenders with prison terms; 2 . An increase in the sanction amount paid by offenders; 3 . Investing in tax education; 4.Others; 5 . Don't know/no answer."

$42.7 \%$ of the respondents believe that enforcing penalties involving deprivation of liberty is most effective. Another $34.4 \%$ are in favour of enforcement measures. $8.9 \%$ consider that investing in tax education is the best option. The percentages in the previous study [9] were $27.5 \%, 50 \%$ and $21.1 \%$, respectively.

Question 8. The participants were asked to say to what extent they agree or disagree with a series of statements. Their responses reveal that:

- the majority of the respondents (92.4\%) disagree with the statement "In general, the effects of tax fraud are not very significant".

- $84.7 \%$ agree to some extent that tax fraud diminishes the resources to finance public services and social provisions.

- $77.1 \%$ agree to some extent that tax fraud implies an increase in the tax burden of those who fulfil their obligation and pay their taxes correctly, while $16.6 \%$ disagree to some extent with this statement.

- $82.2 \%$ agree that tax fraud demotivates those who pay their taxes correctly (as opposed to $14 \%$ who disagree).

- $78.9 \%$ agree that tax fraud creates unfairness as some people pay what others are not paying.

- $3.2 \%$ consider that committing fraud is not harmful to anyone. On the other hand, $92.4 \%$ disagrees with this statement.

- the majority of the respondents $(81.5 \%)$ disagree with the statement "Tax fraud can be justified because too much is paid to the State".

- the majority of the respondents $(68.8 \%)$ disagree with the statement "Tax fraud can be justified because of the fact that the richest people do not pay what corresponds to them" (as opposed to $21.7 \%$ who agree).

- $60.5 \%$ disagree with the statement "Tax fraud can be justified because fraud control is insufficient" (as opposed to $29.3 \%$ who agree).

- $52.9 \%$ agree that if people do not commit more tax fraud it is because they fear an inspection (as opposed to $40.1 \%$ who disagree). This is highly significant as it shows that the perception of 
the sample is that people pay not because they are aware or responsible or feel solidarity but because they are coerced, that is, through fear of their fraud being detected and the likely sanction. Therefore, the utopia of a voluntary and amicable payment is not achievable.

- $43.3 \%$ agree to some extent that almost everybody underreports when paying their taxes, and the Authorities assume this, while $49 \%$ disagree to some extent with this statement.

- the majority of the respondents $(65.6 \%)$ agree with the statement "Cheating the tax authority is cheating the rest of the population".

\section{CONCLUSIONS}

The conclusions that can be drawn from the results of this questionnaire are that the students surveyed seem to know the ultimate purpose of taxes, believe that the taxes paid to the state do not benefit society very much and that the Spanish taxation system is not fair. The most-commonly given reason for the latter is that fraud control is not effective (one third of the respondents said that the tax authority is not effective in the fight against fraud), followed by "those who have more do not pay what corresponds to them". In spite of this, it should be noted that more than $75 \%$ of the participants believed that fraud is not justifiable under any circumstance.

The underlying perception of the last response that "those who have more do not pay what corresponds to them" is notable as it raises questions such as: How do the survey participants know that those who have more do not pay what corresponds to them? Who is responsible for this opinion? ...the Tax Authority?... the media?...

It is unquestionable that, for certain taxes, the majority of tax benefits are not applied to small taxpayers but designed for high income earners. Therefore, the ultimate responsibility for this matter corresponds to the legislator when granting tax privileges. However, can this justify fraud committed by individual taxpayers who are not eligible to these deductions established in the tax regulations? $A$ priori it would not be justified. Maybe the "injustice" could be taken to the competent courts. If these judicial authorities allow some to benefit more than others, then it could be considered that these individuals have the right to commit fraud as a form of "self-help".

But that as it may, the results show a dissatisfaction with the legislation as the law in force does not seem to respect the principle of progressiveness, enabling those who have more to make better use of the tax benefits. This gives rise to a feeling of unfairness and creates a social divide which, in turn, leads to a high percentage of individuals justifying fraud.

On the other hand, it is worth mentioning that university students seem to have internalised the fact that all citizens commit tax fraud.

Finally, it is worth highlighting that the respondents value coercive measures $(77.1 \%)$ more than tax education (8.9\%) in the fight against fraud. Criminal accountability is an obvious deterring factor because everyone in some way usually weighs up the pros and cons of their behaviour. But as pointed out by Giachi [13], criminal responsibility is only a highly effective factor in the case of smallscale fraud. Therefore, and despite the percentages of the responses received, we consider that a better tax education would contribute to changing the social behaviour of tolerance towards fraud and the offenders as it would modify culturally-rooted behaviour and give rise to a social climate which is less influential on the conduct of taxpayers. We based this statement in the fact that the results obtained in this study are, in general terms, better than the obtained in the previous one [9] and the main difference between the samples is that now we are asking students of Management and Business studies after receiving a specific course on taxation.

\section{REFERENCES}

[1] Park, Hyun., "Examining the determinants of tax compliance by experimental data: A case of Korea", Journal of Policy Modeling, no. 25 (8), 2003.

[2] Eriksen, Fallan, "Tax knowledge and attitudes towards taxation. A report on a quasiexperiment", Journal of Economic Psychology, no. 17, pp. 387-402, 1996.

[3] Vogel, J., "Taxation and public opinion in Sweden: An interpretation of recent survey data", National Tax Journal, no. 28(4), pp. 499-513, 1974. 
[4] Spicer, M.W., Lundstedt, S.B., "Understanding tax evasion", Public Finance, no. 31(2), pp. 295305, 1976.

[5] Song, Y., Yarbrough T.E,. "Tax Ethics and Taxpayer Attitudes: A survey", Public Administration Review, no. 38, pp. 442-457, 1978.

[6] Laurin, U., Pa Heder och Samvete. Skattefuskets Orsaker och Utbredning. Stockholm: Norstedts Förlag, 1986.

[7] Kinsey K.A., Grasmick, H.G., "Did the tax reform act of 1986 improve compliance? Three studies of pre- and post-TRA compliance attitudes", Law and Policy, no. 15(4), pp. 293-325, 1993.

[8] Prieto, J. Sanzo, M. J., Suarez Pandiello, J., "Analisis económico de la actitud hacia el fraude fiscal en España", Hacienda Pública Española: Review of Public Economics, no. 2, pp. 107128, 2006.

[9] Sarasa, C.P., Sarasa-Pérez, J., Moya-Auñón, B.A, "Students' attitudes towards tax fraud in Spanish universities", ICERI 2015 Proceedings. pp. 4504-4508, 2015.

[10] Centro de estudios Sociológicos. CIS., Opinión pública y política fiscal. < http://www.cis.es/cis/export/sites/default/-Archivos/Marginales/3020_3039/3034/es3034mar.pdf $>$ [12/07/2016], 2014.

[11] Spicer, M.W., Becker, L.A., "Fiscal inequality and tax evasion: An experimental approach", National Tax Journal, no. 33, 2, pp. 171-175, 1980.

[12] Gutiérrez Lousa, M., "Ética y Fiscalidad". Revista ICE, no. 823, pp. 111-115, 2005.

[13] Giachi, S., "Dimensiones sociales del fraude fiscal: confianza y moral fiscal en la España contemporánea", Revista Española de Investigaciones Sociológicas, no.145, pp. 73-98, 2014. 